\title{
Psychological and pedagogical conditions for the development of professional abilities of future teachers
}

\author{
E.A. Ramazanova ${ }^{1 *}$, and M.L. Shabdinov ${ }^{2}$ \\ ${ }^{1}$ State Budget Educational Institution of Higher Education of the Republic of Crimea Crimean \\ Engineering and Pedagogical University the name of Fevzi Yakubov, Simferopol, Russia \\ ${ }^{2}$ State Budget Educational Institution of Higher Education of the Republic of Crimea Crimean \\ Engineering and Pedagogical University the name of Fevzi Yakubov, Simferopol, Russia
}

\begin{abstract}
The article describes features of the development of professional abilities of future teachers. Different views of scientists on the definition of "professional abilities" are considered, the development of which, in turn, affects the effectiveness of professional pedagogical activity. The role of the educational process in higher education as a platform for the development of professional and pedagogical abilities is noted. The pedagogical conditions that contribute to the effectiveness of the development of students' professional abilities are highlighted and substantiated. The article describes the results of experimental work to identify the current level of development of professional abilities of future teachers. At the initial and control stages, monitoring and a number of diagnostic techniques were used, as well as self-diagnostics. The formative stage of the experimental research is represented by the testing of the selected pedagogical conditions. According to the results of the control section, the dynamics of the level of development of the professional abilities of future teachers in a positive direction was observed.
\end{abstract}

\section{A problem statement}

A drastic reform of the Russian society, accompanied by radical changes in all spheres of life, requires the renewal of all social institutions and systems, including the educational one. The system of Russian education at the present stage of development is undergoing significant changes associated, first of all, with the change of educational paradigms, the transition from the level of knowledge to the level of competencies.

In modern conditions, there is a high demand for a socially active, creative person who is able to independently make decisions and personally be responsible for their implementation. As a result, professional requirements for the performer of the tasks set by modernization - a teacher - also increase, namely, there is a shift in emphasis from professional knowledge to the level of professional competencies and the subject position

\footnotetext{
*Corresponding author: prof-ped.gpa@mail.ru
} 
of the teacher in the implementation of professional activities. It should also be noted that the current situation increases the complexity of a teacher's professional and pedagogical activity, associated, first of all, with constant intellectual and emotional stress, overcoming psychological difficulties.

\subsection{The objective of the work}

The study of pedagogical abilities was carried out by the following authors: S.T. Nyshanova [1], L. Rutten [2] and others, who were among the first to address the problem of professional abilities of future teachers. Many modern researchers have also addressed this topic, including S.K. Berdibayeva [3], M. Sirotová [4], R. Massyrova [5] and others.

Also in the psychological and pedagogical literature, much attention is paid to the study of influence of the development level of pedagogical abilities on the productivity of professional pedagogical activity (U. Khakimhan [6], M. Ulbosyn [7], etc.). These researchers prove that the effectiveness of professional pedagogical activity, the skill of teachers is largely determined by the developed pedagogical abilities.

Scientific works of R. Sydykova [8], I.V. Zotova [9], who proposed a list of the most significant professional abilities for a future teacher, are of a specific interest.

Results of the research by E.Yu. Ponomareva [10], Mazilov V.A. [11], Yu.P. Zinchenko [12], I.A. Korebeinikov [13], E.G. Belyakov [14] provide grounds for determining psychological and pedagogical conditions for the development of professional abilities of future teachers. Although the modern psychological and pedagogical literature has accumulated extensive material devoted to the problem of the development of pedagogical abilities, special works on creating conditions for the development of professional abilities of future teachers of an educational organization are not enough. The professional abilities of a teacher are understood as a set of individual psychological characteristics of a teacher's personality and his professionally significant qualities, which meets the requirements of pedagogical activity and determines success in mastering this activity.

\section{Results of the research}

Professional abilities of a teacher provide a high level of general development and the fact that other special abilities are included in the sphere of pedagogical activity only if there is a pedagogical orientation and pedagogical abilities in the context of their further development. Pedagogical abilities provide the accumulation of useful information about pupils, which allows the use of "creative" proposals, stimulating the formation of selfcontrol and self-regulation, thus guaranteeing the student's needs for self-development and self-affirmation.

Professional abilities of a teacher are an important prerequisite for the successful mastery of the teaching profession and reflect the quality of the personality, expressed in the inclination to work with pupils, love for them and the pleasure of communicating with them. Suitability (predisposition) is determined by the anatomical, physiological, psychophysiological and psychological characteristics of a person, which allows him to perform actions such as "Human-Human" interaction. A person's suitability for pedagogical activity is based on normal intellectual development, empathy, scenic emotions, a normal level of development of communicative and cognitive activity.

The professional abilities of a teacher include: didactic, academic, perceptual, verbal, communicative, organizational, authoritarian, predictive, as well as the ability to distribute attention. 
In the problem of the professional abilities of a teacher, much attention is paid to their development. Any modern teacher will be able to fully realize their professional potential, depending on the depth of understanding of the essence of education.

Training of a future teacher in higher education is determined by many factors, and not only by the degree of his preparedness in the field of the foundations of science. Higher school of pedagogical orientation is designed to form the foundations of pedagogical skills during the period of student training, to provide a minimum of skills that would allow the majority of graduates to become masters of pedagogical work without undue delay. A training system for a future teacher of an educational organization should give students a deep understanding of the specifics of this activity and the requirements that it imposes on the personal qualities of a teacher; to provide a fairly high degree of training of all pedagogical components in future teachers.

The tasks of improving the training of teachers in a pedagogical educational organization determine the need to pay special attention to the training of pedagogical skills among students precisely during the period of vocational and pedagogical education.

The analysis of the work reveals the main methods and conditions for the development of the professional abilities of future teachers of the educational organization during professional training:

- the formation within the boundaries of educational work of the coordinated cooperation of the entire teaching staff, which is associated with the implementation of the task of purposeful formation and development of pedagogical abilities;

- the introduction of extra-curricular forms of work, for example, special electives, courses aimed at developing the necessary components of pedagogical abilities;

- building a system of self-development of students' pedagogical abilities and managing it by analyzing and assessing the level of development of individual components of pedagogical abilities; as well as drawing up individual self-education programs, monitoring and evaluating the self-education process.

We can say that the entire pedagogical process should be aimed at developing the professional abilities of future teachers. The educational process here acts as a kind of pedagogical practice, during which students can analyze it not only from the standpoint of an ordinary person, but also from the professional side: they not only pass exams, but learn to take them; not only attend lectures, but also learn to deliver them; not only communicate with other students of higher education, but also learn to build relationships in a team. Students have every opportunity to analyze the teaching styles, techniques and methods of their teachers; to develop reflective skills.

The development of professional abilities is one of the most important conditions for improving a professional activity of a specialist; in the training of future teachers, it can be applied in the following conditions:

- ensuring the subjective position of a student in the educational process, which creates conditions for independent determination and awareness of the reasons, tasks, choice of means and conditions of their activity, awareness of the results obtained;

- translation of educational and professional problems into vital problems of students, which require updating and transformation of their subjective holistic experience;

- building a system of relationships between a teacher and students on the basis of openness, trust, dialogue, creating conditions for self-disclosure of creative potential and their self-realization.

Thus, the psychological and pedagogical conditions for the development of the professional abilities of future teachers of an educational organization can be presented as a unity of content, organizational and motivational components.

Based on the topic of our research, when choosing components of the development of professional abilities of future teachers of an educational organization and their formation 
in the psychological and pedagogical conditions of higher education, we relied on the classification of professional pedagogical abilities by E. Enns [15], D. Matukhin [16] and P. Mihaela [17], N.Yu. Belikova [18], E.A. Shereshkova [19], E. Urunbassarova [20], B.S. Haug [21] since they are based on a system-activity approach to learning and a personalityoriented approach.

A systematic psychological and pedagogical assessment of the development level of professional abilities helps students to obtain objective information about features of the development of their abilities, as for future teachers - to correctly develop a program for self-development of professional abilities, for current teachers - to adequately build an educational process in higher education. During the development of abilities, it is necessary to take into account the motivation of a person, since the development process is impossible without one's own active work.

It is thanks to abilities that a person becomes a subject of activity in society, thanks to development - that he reaches the top in a professional and personal sense, becomes competent in a certain area of professional activity.

The criteria for assessing the professional abilities of future teachers of an educational organization were determined: communicative, organizational, gnostic, didactic, reflexive, constructive. Further, to assess the development level of professional abilities of future teachers in psychological and pedagogical conditions, at the beginning of the experiment, monitoring was carried out in the control and experimental groups. In the experimental work, diagnostic tools were used, which included methods tested in psychological and pedagogical research.

The purpose of the formative stage is to check the effectiveness of the complex of psychological and pedagogical conditions for the development of professional abilities of future teachers.

At this stage of the work, a pedagogical experiment was purposefully carried out to organize psychological and pedagogical conditions for the development of the professional abilities of future teachers in the direction of training pedagogical education.

We have identified the following conditions as conducive to an effective development of professional abilities of future teachers:

1. taking into account basic principles of the development of professional abilities;

2. development of educational and methodological complexes;

3. mastering by future teachers of methods of working with educational and methodological complexes.

These conditions were implemented by us in the framework of the disciplines of the pedagogical module with the students of the higher school of the 4th year of pedagogical profile.

The proposed psychological and pedagogical conditions for the development of professional abilities of future teachers include a number of interrelated components: approaches to the professional training of future specialists, educational and methodological complexes, active forms and methods of teaching. One of the most important components of psychological and pedagogical conditions, in our opinion, are educational and methodological complexes.

Providing higher school students with educational and methodological complexes helped to assimilate new material, individualize learning, improve control and self-control, free up time for creative, research work, and, consequently, increase the efficiency of the educational process.

Students were offered a set of diagnostic techniques to assess the professional abilities of a future teacher. The students entered these self-diagnostics into the "workbook", in particular, by discipline. Keeping a workbook allowed students to independently track changes in the development of professional abilities (since diagnostics and self-diagnostics 
were carried out systematically), in addition to this, in this notebook, future teachers performed other various tasks: "drew" a portrait of a future teacher (mini-essay), made a teacher's professiogram, developed control questions, rebuses and crosswords to test students' knowledge on certain topics of the courses "Psychology" or "Pedagogy", etc.

The implementation of course projects provides a deeper penetration into the problem of professional abilities, makes future teachers think about their own professional level, stimulates to improve it, and an interesting and successful defense of the work performed made it possible to draw the attention of other students to the problem of developing the professional abilities of teachers. When implementing course design, the development of all professionally important abilities of the future teacher was ensured.

Thus, all the structural components of educational and methodological complexes in the disciplines of subject training were developed by us with a focus on the development of the professional abilities of future teachers. The effectiveness of the developed psychological and pedagogical conditions was tested during a control experiment, the results of which are described below (see Table 1).

Table 1. Generalized results of assessment by future teachers of the importance of professional abilities components obtained during the experiment.

\begin{tabular}{|c|c|c|c|c|c|c|c|c|}
\hline \multirow{3}{*}{$\begin{array}{c}\text { Components of } \\
\text { professional } \\
\text { ability }\end{array}$} & \multicolumn{6}{|c|}{ Significance in pedagogical activity } & \multirow{2}{*}{\multicolumn{2}{|c|}{ Total }} \\
\hline & \multicolumn{2}{|c|}{ Significant } & \multicolumn{2}{|c|}{ Less significant } & \multicolumn{2}{|c|}{$\begin{array}{l}\text { Not much } \\
\text { significant }\end{array}$} & & \\
\hline & $\begin{array}{c}\text { Amount } \\
\text { of } \\
\text { people }\end{array}$ & $\begin{array}{c}\text { Amount } \\
\text { in per } \\
\text { centage } \\
\% \\
\end{array}$ & $\begin{array}{c}\text { Amount } \\
\text { of } \\
\text { people }\end{array}$ & $\begin{array}{c}\text { Amount } \\
\text { in per } \\
\text { centage } \\
\% \\
\end{array}$ & $\begin{array}{c}\text { Amount } \\
\text { of } \\
\text { people }\end{array}$ & $\begin{array}{c}\text { Amount } \\
\text { in per } \\
\text { centage } \\
\% \\
\end{array}$ & $\begin{array}{c}\text { Amount } \\
\text { of } \\
\text { people }\end{array}$ & $\begin{array}{c}\text { Amount } \\
\text { in per } \\
\text { centage } \\
\% \\
\end{array}$ \\
\hline $\begin{array}{l}\text { The constructive } \\
\text { one }\end{array}$ & 15 & 75 & 5 & 25 & - & & 20 & 100 \\
\hline $\begin{array}{l}\text { The } \\
\text { organizational one }\end{array}$ & 16 & 80 & 4 & 20 & - & & 20 & 100 \\
\hline $\begin{array}{l}\text { The } \\
\text { communicative } \\
\text { one }\end{array}$ & 17 & 85 & 3 & 15 & - & & 20 & 100 \\
\hline The didactic one & 16 & 80 & 4 & 20 & - & & 20 & 100 \\
\hline The Gnostic one & 14 & 70 & 6 & 30 & - & & 20 & 100 \\
\hline The reflexive one & 13 & 65 & 7 & 35 & - & & 20 & 100 \\
\hline
\end{tabular}

These results in the table indicate that the significance of all components has increased, especially of the constructive, didactic, gnostic and reflective ones. So, if at the beginning of the experiment the respondents assessed the significance of the constructive component in pedagogical activity by $40 \%$, then at the end - already by $75 \%$. Future teachers of the educational organization began to regard all the proposed components as significant (to one degree or another).

And in conclusion, the dynamics of the development level of professional abilities of future teachers was considered separately for each of the groups that took part in the experiment.

The results show that there were no significant changes in the control group. The data presented in Table 2 indicate that there have been changes in the development of all diagnosed professional abilities in future teachers from the experimental group. Higher results are noted for communicative, organizational and didactic abilities, the gnostic component (see Table 2). 
Table 2. Generalized results of assessing the development level of professional abilities of future teachers, obtained during the experiment.

\begin{tabular}{|c|c|c|c|c|c|c|}
\hline \multirow{2}{*}{ Abilities } & \multicolumn{2}{|l|}{ Low } & \multicolumn{2}{|l|}{ Medium } & \multicolumn{2}{|l|}{ High } \\
\hline & $\begin{array}{l}\text { Const. } \\
\text { stage }\end{array}$ & $\begin{array}{l}\text { Contr. } \\
\text { stage }\end{array}$ & $\begin{array}{l}\text { Const. } \\
\text { stage }\end{array}$ & $\begin{array}{l}\text { Contr. } \\
\text { stage }\end{array}$ & $\begin{array}{l}\text { Const. } \\
\text { stage }\end{array}$ & $\begin{array}{l}\text { Contr. } \\
\text { stage }\end{array}$ \\
\hline \multirow[t]{2}{*}{ Communicative } & 2 people & 1 person & 3 people & 2 people & 5 people & 8 people \\
\hline & $20 \%$ & $10 \%$ & $30 \%$ & $20 \%$ & $50 \%$ & $80 \%$ \\
\hline \multirow[t]{2}{*}{ Organizational } & 4 people & 2 people & 3 people & 3 people & 3 people & 5 people \\
\hline & $40 \%$ & $20 \%$ & $30 \%$ & $30 \%$ & $30 \%$ & $50 \%$ \\
\hline \multirow[t]{2}{*}{ Gnostic } & 4 people & 2 people & 4 people & 4 people & 2 people & 4 people \\
\hline & $40 \%$ & $20 \%$ & $40 \%$ & $40 \%$ & $20 \%$ & $40 \%$ \\
\hline \multirow[t]{2}{*}{ Didactic } & 3 people & 1 person & 4 people & 4 people & 3 people & 5 people \\
\hline & $30 \%$ & $10 \%$ & $40 \%$ & $40 \%$ & $30 \%$ & $50 \%$ \\
\hline \multirow[t]{2}{*}{ Reflexive } & 5 people & 1 person & 3 person & 5 people & 2 people & 4 people \\
\hline & $50 \%$ & $10 \%$ & $30 \%$ & $50 \%$ & $20 \%$ & $40 \%$ \\
\hline
\end{tabular}

In the course of the experimental work, the effectiveness of the proposed psychological and pedagogical conditions for the development of the professional abilities of future teachers of the educational organization was proved. They began to manifest themselves more qualitatively, the level of development of various components of professional abilities increased. The dynamics in the development of organizational and communication skills of the respondents is more noticeable; gnostic, didactic and reflexive abilities are described at the middle level of development. The orientation of future teachers of an educational organization to work in a team, readiness for self-knowledge and self-development has increased; there was an increase in the development of professional abilities.

\section{Conclusions}

In the course of the experimental work, the effectiveness of the proposed psychological and pedagogical conditions for the development of the professional abilities of future teachers was proved. They began to manifest themselves more qualitatively, the level of development of various components of professional abilities increased. The dynamics in the development of organizational and communication skills of the respondents is more noticeable; gnostic, didactic and reflexive abilities are described at the middle level of development. The orientation of future teachers to work in a team, readiness for selfknowledge and self-development has increased; there was an increase in the development of professionally important qualities. Thus, the results of the experimental work confirmed that the implementation of the proposed psychological and pedagogical conditions in the educational process ensures the effective development of professional abilities among the participants of the experimental group - future teachers.

\section{References}

1. S.T. Nyshanova, B.M. Baimukhanbetov, U.M. Abdigapbarova, B.K. Mukhamedzhanov, Developing Future Teachers Creative Abilities in Competence Oriented Educational Process of High School, Procedia - Social and Behavioral Sciences, 116, 4287-4292. (2014)

2. L. Rutten, Toward a theory of action for practitioner inquiry as professional development in preservice teacher education, Teaching and Teacher Education, 97, (2021) 
3. S. K. Berdibayeva, A. M. Kalmatayeva, Sholpan A. Tulebayeva, Research of Formation of Personal-Professional Capacities at Higher Education Institutes Students of Pedagogical Specialties, Procedia - Social and Behavioral Sciences, 69, 1174-1177. (2012)

4. M. Sirotová, Pedagogical Praxis as a Process of Developing Professional Competencies in University Education of Future Teachers, Procedia - Social and Behavioral Sciences, 228, 529-534. (2016)

5. R. Massyrova, T. Bainazarova, K. Meterbayeva, I. Smanov, G. Smanova, Future Teacher Training for the Children Under School Age Reative Abilities Development, Procedia - Social and Behavioral Sciences, 190, 164-168. (2015)

6. U. Khakimhan, U. Sakypzhamal, B. Zhanat, Humanization of the Pedagogical Process is the Basis of Professionally Mobile Training of a Future Teacher, Procedia - Social and Behavioral Sciences, 116, 5152-5155. (2014)

7. M. Ulbosyn, T. Batima, O. Yessen, A. Bulatbayeva, A. Ergalieva, Psychological Aspects of Formation the Professional Competence of the Future Specialists, Procedia - Social and Behavioral Sciences, 185, 276-280. (2015)

8. R. Sydykova, L. Kakimova, B. Ospanov, A. Tobagabylova, U. Kuletova, A conceptual approach to developing the creativity of a music teacher in modern educational conditions, Thinking Skills and Creativity, 27, 160-166. (2018)

9. I.V. Zotova. Formation of professional and pedagogical abilities of future ECE teachers through innovative activities. Problems of modern pedagogical education. 69 (2), 77-81. (2020)

10. E.Y. Ponomareva. Psychological and pedagogical aspects of the development of the ability for empathy in future teachers in the context of their professional education in higher education "Problems of modern pedagogical education, 62(1), 387-389. (2019)

11. V. A. Mazilov, Yu.N. Slepko. Development of social abilities of students of the pedagogical university. Integration of Education, 24(3), 412-432. (2020)

12. I. A. Korobeinikov, T. V. Kuzmichev. Mastering professional competencies by future teachers and psychologists in the course of joint training at the university. Higher education in Russia, 6, 97-106. (2019)

13. E.G. Belyakova, I.G. Zakharova. Professional self-determination and professional identity of student teachers in the context of individualization of education. Education and Science, 22(1), 84-112. (2020)

14. E. Enns, M. Shapovalova, Psycho-Pedagogical Model of Students' Professional Consciousness Development, Procedia - Social and Behavioral Sciences, 214, 385392. (2015)

15. D. Matukhin, D. Bolgova, Learner-centered Approach in Teaching Foreign Language: Psychological and Pedagogical Conditions, Procedia - Social and Behavioral Sciences, 206, 148-155. (2015)

16. P. L. Mihaela, Dimensions of Teaching Staff Professional Competences, Procedia Social and Behavioral Sciences, 180, 924-929. (2015)

17. N.Yu. Belikova, E.U. Ponomareva, V.V. Kotlyarova, S.V. Yushina, L.I. Abbasova, A.T. Latysheva, Professional and social self-determination of youth under conditions of the modernization of higher education. Revista Genero e Direito. 9(4), 846-859. (2020) 
18. E. A. Shereshkova, O. V. Konovalova, Yu.M. Edikhanova, O.A. Spitsyna, E.A. Volgusnova. Self-actualization in the structure of the personal potential of future teachers. Prospects for Science and Education, 4(40), 274-293. (2019)

19. E. Urunbassarova, M. Jandildinov, E. Uaidullakyzy, F. Teachers Professional Competence Development within Bachelor Program, Procedia - Social and Behavioral Sciences, 116, 4829-4833. (2014)

20. B.S. Haug, S.M. Mork, Taking 21st century skills from vision to classroom: What teachers highlight as supportive professional development in the light of new demands from educational reforms, Teaching and Teacher Education, 100, (2021) 